\title{
INSTITUTE OF GEOLOGICAL SCIENCES RADIOCARBON DATES V
}

\author{
E WELIN, L ENGSTRAND, and S VACZY
}

Radioactive Dating Laboratory, S-10405, Stockholm 50, Sweden*

This date list was compiled by the Institute of Geological Sciences (UK) incorporating data supplied under contract by E Welin, Radioactive Dating Laboratory, Stockholm. Unless otherwise stated, age figures are in ${ }^{14} \mathrm{C}$ years before $\mathrm{AD} 1950$. The half-life of ${ }^{14} \mathrm{C}$ is taken as 5568 years and the error, based on counting statistics of sample, background, and modern, is given as one standard deviation. Correction for ${ }^{13} \mathrm{C} /{ }^{12} \mathrm{C}$ fractionation has been made. \section{$6300 \mathrm{BC}$ \\ $\delta^{13} \mathrm{C}=-31.0 \%$}

Peat from $-26.36 \mathrm{~m}$ OD in borehole in Medway estuary $\left(51^{\circ} 26^{\prime} \mathrm{N}\right.$, $0^{\circ} 43^{\prime}$ E, Grid Ref TQ 8850 7410). Peat $3 \mathrm{~m}$ thick, overlain by $19 \mathrm{~m}$ estuarine clays and resting on gravel, in buried channel in London Clay. Coll 1971 and subm by G J Penney, Inst Geol Sci. Comment (GJP): date suggests channel was infilled during Holocene rise in sea-level. \section{BC \\ $\delta^{13} C=-25.3 \%$}

Wood $0.5 \mathrm{~m}$ below top of diatomite bed $1 \mathrm{~m}$ thick forming part of terrace $2 \mathrm{~m}$ above Lough Neagh $\left(54^{\circ} 45^{\prime} \mathrm{N}, 6^{\circ} 28^{\prime} \mathrm{W}\right.$, Irish Grid Ref H 984 907). Coll 1971 and subm by R A Old, Inst Geol Sci. Comment (RAO): determination gives age of Neolithic 'Bann Culture' in diatomite assigned to Zone VIIb by Jessen (1949).

\section{Bingley series}

\section{IGS-C14/91. (St 3850) Airedale, Yorkshire \\ $11,135 \pm 110$ \\ 9185 BC \\ $\delta^{13} C=-31.0 \%$}

Peat ca $0.15 \mathrm{~m}$ thick at $2 \mathrm{~m}$ depth from trial trench near Bingley $\left(53^{\circ}\right.$ $51^{\prime} \mathrm{N}, 1^{\circ} 5 \mathrm{l}^{\prime} \mathrm{W}$, Grid Ref SE 101390$)$. Peat lies on laminated clay in hollow at rear of rotational landslip involving till and soliflucted till and is overlain by ca $0.5 \mathrm{~m}$ laminated clay and a solifluction mantle ca $1.5 \mathrm{~m}$ thick. Coll 1971 and subm by J N Hutchinson, Imperial College, London. Comment $(\mathrm{JNH})$ : confirms pollen analysis which suggested Zone II age (J Turner, Univ Durham) and limiting date for landslip.

* Published by permission of the Director, Institute of Geological Sciences, Exhibition Road, London SW7. The Institute is a contracting agency, not a dating laboratory, yet IGS at London is the "author" when needed for inter-laboratory communication. 
IGS-C14/92. (St 3870) Airedale, Yorkshire

$\delta^{13} C=-28.5 \%$

Stems of Alnus glutinosa, id by K L Alvin, Imperial College, in growth position from top of peat referred to in IGS-C14/91.

IGS-C14/93. (St 3871) Trafalgar Square, London

$$
\begin{array}{r}
>\mathbf{4 0 , 0 0 0} \\
\delta^{13} \mathrm{C}=-30.7 \% \circ
\end{array}
$$

Plant stem fragments from peat $150 \mathrm{~mm}$ thick at $0.6 \mathrm{~m}$ OD in Flood Plain Terrace deposits, Carlton House Terrace Redevelopment site $\left(51^{\circ}\right.$ $30^{\prime} \mathrm{N}, 0^{\circ} 8^{\prime} \mathrm{W}$, Grid Ref TQ 29818033$)$. Coll 1971 and subm by B C Worssam, Inst Geol Sci. Comment (BCW): date accords with Ipswichian age deduced from flora and fauna from previous excavations in vicinity (Franks et al, 1958; Franks, 1960).

\section{IGS-C14/94. (St 3846) Stanway By-pass, Essex}

$\mathbf{2 8 , 1 7 0} \pm \mathbf{7 0 0}$ $26,220 \mathrm{BC}$ $\delta^{13} \mathrm{C}=-29.2 \%$

IGS-C14/95. (St 3864) Stanway By-pass, Essex

Peat from cutting $\left(51^{\circ} 53^{\prime} \mathrm{N}, 0^{\circ} 48^{\prime} \mathrm{E}\right.$, Grid Ref TL 9257 2425). Coll 1971 and subm by C R Bristow, Inst Geol Sci. Comment (F C Cox): stratigraphic and palynologic evidence favors correlation with the Hoxnian. Samples were not treated with $\mathrm{NaOH}$ to dissolve humic matter. The stratigraphically younger specimen (IGS-C14/95) yielded older date; thus, samples must have been contaminated by humic solutions.

\section{IGS-C14/96.}

\section{(St 3903) Brantingham, Yorkshire}

$21,835 \pm 1660$

$19,885 \mathrm{BC}$

$\delta^{13} C=-32.8 \%$

Bone fragment from temporary excavation in sand and gravel SW of Brantingham (53 $45^{\prime} \mathrm{N}, 0^{\circ} 35^{\prime} \mathrm{W}$, Grid Ref SE 9385 2918). Depth $3.05 \mathrm{~m}$ below surface. Coll 1970 and subm by G D Gaunt, Inst Geol Sci. Comment: bone occurred within or at base of littoral sediments attributed to maximum elevation phase of 'Lake Humber'. Date indicates an upper Devensian age for this phase and supports stratigrahic evidence that it was approx contemporaneous with the maximum Devensian ice advance into the Vale of York.

\section{Stoneferry series, Yorkshire}

Peat and shells from excavation at Stoneferry, Hull $\left(53^{\circ} 46^{\prime} \mathrm{N}, 0^{\circ}\right.$ 20' W, Grid Ref TA 1036 3214). Coll 1971 and subm by G D Gaunt, Inst Geol Sci.

\section{IGS-C14/97. (St 3812)}

$$
\begin{aligned}
& \mathbf{5 2 4 0} \pm 100 \\
& \mathbf{3 2 9 0} \text { BC }
\end{aligned}
$$

Peat from $5.7 \mathrm{~m}$ below surface. 


\section{IGS-C14/98 I. (St 3803)}

$3775 \pm 100$

$1825 \mathrm{BC}$

$\delta^{13} \mathrm{C}=-4.3 \%$

Shells (Cerastoderma edule) from base of estuarine sediments in same excavation as $/ 97$ at $5.5 \mathrm{~m}$ below surface.

IGS-C14/98 II. (St 3804)

$3435 \pm 200$

$1485 \mathrm{BC}$

$\delta^{13} \mathrm{C}=-5.8 \%$

Shells (Macoma balthica) from base of estuarine sediments in same excavation as /97 and at same depth as /98 I.

\section{Hull series, Yorkshire}

Peat from borehole at Market Place, Hull $\left(53^{\circ} 44^{\prime} \mathrm{N}, 0^{\circ} 20^{\prime} \mathrm{W}\right.$, Grid Ref TA 1003 2851). Coll 1971 by J Bartlett, Hull Mus, and subm by G D Gaunt, Inst Geol Sci.

\section{IGS-C14/99. (St 3845)}

$$
\begin{gathered}
\mathbf{6 9 7 0} \pm 100 \\
\mathbf{5 0 2 0} \mathbf{B C} \\
\delta^{13} \mathrm{C}=-29.5 \%
\end{gathered}
$$

Sample from base of peat bed, $16.15 \mathrm{~m}$ below surface, in borehole.

IGS-C14/100. (St 3825)

$$
6890 \pm 100
$$

$$
\begin{gathered}
4940 \mathrm{BC} \\
\delta^{13} \mathrm{C}=-28.8 \%
\end{gathered}
$$

Sample from upper part of peat bed in same borehole as /99.

General Comment on IGS-C14/97-100 (GDG): dates help determine relative rise of Flandrian sea level in Humber region. Dates for /98I and 98II show extent of variation between two species of shells from same horizon; date from $M$ balthica, the thinner-shelled species is younger and has a wider margin of uncertainty.

\section{IGS-C14/101. (St 3805, outer fraction)} Ballykelly, Co Londonderry

\section{(St 3806, inner fraction) Ballykelly, Co Londonderry}

$$
\begin{array}{r}
\mathbf{2 8 , 7 2 0}+\mathbf{9 1 0} \\
\mathbf{6 2 0} \\
\mathbf{2 6 , 7 7 0} \mathbf{\mathrm { BC }} \\
\delta^{13} \mathrm{C}=+5.5 \% \mathrm{C} \\
>\mathbf{4 0 , 0 0 0} \\
\delta^{13} C=+0.3 \%
\end{array}
$$

Shells from deeply cut Londonderry Lower Till exposed in stream sec at Thorny Hill, Northern Ireland $\left(55^{\circ} 02^{\prime} \mathrm{N}, 7^{\circ} 02^{\prime} \mathrm{W}\right.$, Irish Grid Ref C 627 210). Coll 1971 and subm by R A B Bazley, Inst Geol Sci. Comment: shells derived from marine sediments of Lough Foyle or North Channel. Age $>40,000$ BP does not confirm theory that widespread lower shelly till of area belongs to an early stage of main Midlandian (Weichsel) glaciation. Present popular theory that this till is Munsterian (Saale) age remains likely. 


\section{Uwchygarreg series, Montgomeryshire}

Samples from lower $1.22 \mathrm{~m}$ of hill-top peat, Ochr Lygnant, Uwchygarreg, Machynlleth (52 $31^{\prime}$ N, $3^{\circ} 46^{\prime} \mathrm{W}$, Grid Ref SN 8001 9163). Total thickness of peat $2.44 \mathrm{~m}$ weathered into vertical face and resting on weathered surface of mudstones.

IGS-C14/103. (St 3834)

From basal $0.08 \mathrm{~m}$ of sediment.

IGS-C14/104. (St 3827)

$0.84 \mathrm{~m}$ above base.

\section{IGS-C14/105. (St 3818)}

$1.22 \mathrm{~m}$ above base.

Coll 1971 and subm by R Cave, Inst Geol Sci.

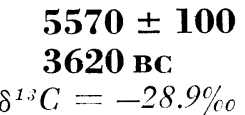

$$
4065 \pm 100
$$$$
2115 \mathrm{BC}
$$

$\delta^{13} \mathrm{C}=-27.3 \%$

$3640 \pm 100$

$1690 \mathrm{BC}$

$\delta^{13} C=-26.2 \%$

\section{IGS-C14/107. (St 3815) Swanscombe, Kent}

$\begin{aligned} & >\mathbf{4 0 , 0 0 0} \\ \delta^{13} \mathrm{C} & =-11.1 \%\end{aligned}$

Shells from a life assemblage of Potomida littoralis Cuvier from sand lens in Lower Loam $0.10 \mathrm{~m}$ above junction with Lower Gravel, NW face of Trench B33 (51 $26^{\prime} \mathrm{N}, 0^{\circ} 18^{\prime} \mathrm{E}$, Grid Ref TQ 59867428$), 1971$ excavations at Barnfield Pit (Conway, 1972). Coll 1971 and subm by B W Conway, Inst Geol Sci. Comment (BWC): Lower Loam widely accepted as Hoxnian (Ovey, 1964) and specifically correlated with early temperate sub-stage of Hoxnian interglacial (Kerney, 1971) occurring within insolation half-cycle $6 \mathrm{~W}$ to which an age of 200,000 to $220,000 \mathrm{yr}$ BP has been assigned (Evans, 1971). As expected, the infinite date is consistent with this.

\section{IGS.C14/108. (St 3830) Hoxne Brick Pit, Suffolk 24,980 BC \\ $\delta^{18} \mathrm{C}=-26.4^{\%} \% \mathrm{c}$}

$26,930 \pm 975$

Peat from Main Cutting, Layer 2, archaeologic excavation $\left(52^{\circ} 21^{\prime}\right.$ N, $1^{\circ} 12^{\prime}$ E, Grid Ref TM 175767 ). Coll 1971 and subm. by C R Bristow. Comment (F C Cox): radiometric age much younger than expected. Stratigraphy and other ${ }^{14} \mathrm{C}$ dates (Bristow and Cox, 1973) suggest sample should be $>40,000 \mathrm{yr}$ and thus must have been contaminated by humic solutions. Sample was not treated with $\mathrm{NaOH}$.

\section{Woodhall Spa series, Lincolnshire}

IGS-C14/109. (St 3831)

$$
\begin{array}{r}
3945 \pm 100 \\
1995 \mathrm{BC} \\
\delta^{13} C=-27.6 \%
\end{array}
$$

Upper layer of peat overlain by blue gray clay and overlying coarse sand containing Humic Gley soil, 2.60 to $2.64 \mathrm{~m}$ below surface at Kirk- 
stead Bridge $\left(53^{\circ} 08^{\prime} \mathrm{N}, 0^{\circ} 15^{\prime} \mathrm{W}\right.$, Grid Ref TF 172619$)$. Coll 1971 and subm by K W G Valentine, Reading Univ.

\title{
IGS-C14/110. (St 3823)
}

\author{
$4155 \pm 100$ \\ 2205 BC \\ $\delta^{13} \mathrm{C}=-27.9 \%$
}

Basal layer of peat in IGS C14/109, immediately overlying the Humic Gley soil in coarse sand, 2.80 to $2.84 \mathrm{~m}$ below surface. Coll 1971 and subm by $\mathrm{K}$ W $\mathrm{G}$ Valentine.

\section{IGS-C14/111. (St 3819)}

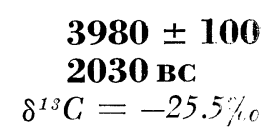

Basal layer of peat overlain by blue gray clay and immediately overlying Humic Gley soil in coarse sand and clay, 2.31 to $2.36 \mathrm{~m}$ below surface at Timberland Dales $\left(53^{\circ} 08^{\prime} \mathrm{N}, 0^{\circ} 14^{\prime} \mathrm{W}\right.$, Grid Ref TF 179602$)$. Coll 1971 and subm by K W G Valentine.

\section{IGS-C14/112. (St 3838) \\ $4130 \pm 100$ $2180 \mathrm{BC}$ \\ $\delta^{13} C=-26.7 \%$}

Basal layer of peat overlain by blue gray clay and immediately ovexlying Humic Podzol soil in coarse sand and gravel, 2.48 to $2.52 \mathrm{~m}$ below surface at Tattershall Bridge $\left(53^{\circ} 05^{\prime} \mathrm{N}, 0^{\circ} 13^{\prime} \mathrm{W}\right.$, Grid Ref TF 186 557). Coll 1971 and subm by K W G Valentine.

General Comment (KWGV): date is latest for development of a Podzol to Gley sequence of paleosols in coarse sands and clay exposed for $\mathrm{ca}$ $10 \mathrm{~km}$ along a gas pipeline trench. IGS-C14/109 and 110 show peat de-veloped quickly over paleosols. All dates are corroborated by pollen analyses, made by B Seddon and S Page, Reading Univ, that gave a consistent spectrum from Zone VII b. Stratigraphically, peat is tentatively correlated with Lower Fen Peat of S fens, but dates are a little later.

\section{St. Ouen's Bay series, Jersey}

IGS-C14/113. (St 3911)

$$
\begin{gathered}
3890 \pm 100 \\
1940 \mathrm{BC} \\
\delta^{13} G=-27.6 \%
\end{gathered}
$$

Peat from 6.1 to $6.6 \mathrm{~m}$ below surface in a borehole $\left(49^{\circ} 14^{\prime} \mathrm{N}, 2^{\circ} 14^{\prime}\right.$ W, Grid Ref 3 SW 1742 0388) at Les Laveurs. Coll 1971 and subm by R G Thurrell, Inst Geol Sci. Comment (RGT): 0.5m peat with sand, interbedded in beach sand sediments of coastal plain, is based at $+2 \mathrm{~m}$ Ory.

\section{IGS-C14/114. (St 3837)}

$$
\begin{gathered}
1925 \pm \mathbf{2 4 0} \\
\operatorname{AD~25} \\
\delta^{13} \mathrm{C}=-27.6 \%
\end{gathered}
$$

Peat from 5.9 to $6.1 \mathrm{~m}$ below surface in a borehole $\left(49^{\circ} 14^{\prime} \mathrm{N}, 2^{\circ} 14^{\prime}\right.$ W, Grid Ref 3 SW 2103 0172) 400m SE of IGS-C14/113. Coll 1971 and subm by R G Thurrell. Comment (RGT): $0.2 \mathrm{~m}$ peat with sand based at $+5.6 \mathrm{~m}$ OD is overlain by sandy beach deposits of St Ouen's coastal plain 
and underlain by predominantly clayey silts and gravelly sands, apparently derived from hinterland.

\section{IGS-C14/115. (St 3833) Sandwich, Kent}

$$
\begin{gathered}
\mathbf{5 3 1 5} \pm \mathbf{1 0 0} \\
\mathbf{3 3 6 5} \text { BC } \\
\delta^{1.3} \mathrm{C}=-27.9 \%
\end{gathered}
$$

Peat from site investigation borehole for Sandwich By-pass $\left(51^{\circ} 17^{\prime}\right.$ $\mathrm{N}, 1^{\circ} 20^{\prime} \mathrm{E}$, Grid Ref TR 3229 5915) in reclaimed estuarine marshland. Coll 1971 by Kent County Council Highways Department and subm by E R Shephard-Thorn, Inst Geol Sci. Comment (ERS-T): borehole commenced at $+3.5 \mathrm{~m}$ OD and proved $3.8 \mathrm{~m}$ fill, overlying $5 \mathrm{~m}$ estuarine silts on solid Thanet Beds; peat occurs as thin bed within silts between -4.0 and $-4.3 \mathrm{~m}$ OD. Date closely compares with those from submerged forest of Pett Level, Sussex (Welin et al, 1972, p 332-333).

\section{$7615 \mathrm{BC}$ \\ $\delta^{13} \mathrm{C}=-29.4 \%$}

Peat from site investigation borehole $\left(50^{\circ} 57^{\prime} \mathrm{N}, 0^{\circ} 44^{\prime} \mathrm{E}\right.$, Grid Ref TQ 9145 2060) in estuarine alluvium of flood plain of $\mathrm{R}$ Tillingham. Coll 1971 by A G Weeks and subm by E R Shephard-Thorn. Comment (ERS-T): borehole, surface ca $+3.5 \mathrm{~m}$ OD, proved $28.80 \mathrm{~m}$ sequence of alluvial silts, sands and clays with organic horizons, overlying Wealden strata. Sample from bed of laminated silty peat between 25.5 and $26.5 \mathrm{~m}$ below surface, just above base of channel. Date compares closely with that from a similar sediment in Cuckmere Valley at Arlington (Welin et al, 1971, p 28) and probably represents same pause early in Flandrian transgression.

\section{Spalding series, Lincolnshire}

Plant fragments and peat from borehole Spalding $1,\left(52^{\circ} 45^{\prime} \mathrm{N}, 0^{\circ}\right.$ 10' W, Grid Ref TF 2368 1923). Coll 1971 and subm by A Horton, Inst Geol Sci.

\section{IGS-C14/117. (St 3851)

Reed rootlets in situ in Fen Clay at depth 3.96 to $4.11 \mathrm{~m}$.

IGS-C14/118. (St 3817)

$4445 \pm 100$

2495 BC

Top of peat seam within Fen Clay at depth 4.54 to $4.57 \mathrm{~m}$.

IGS-C14/119. (St 3849)

$4890 \pm 100$

2940 BC

$\delta^{13} \mathrm{C}=-28.5 \%$

Top of lower peat seam within Fen Clay at depth 7.11 to $7.16 \mathrm{~m}$. 


\section{IGS-C14/120. (St 3848)}

$5665 \pm 100$

3715 BC

$\delta^{13} \mathrm{C}=-28.5 \%$

Base of lower peat seam within Fen Clay at depth 7.62 to $7.67 \mathrm{~m}$.

Peat from borehole Spalding 2, $\left(52^{\circ} 45^{\prime} \mathrm{N}, 0^{\circ} 9^{\prime} \mathrm{W}\right.$, Grid Ref TF 2427 1919). Coll 1971 and subm by A Horton.

IGS-C14/121. (St 3844)

$5175 \pm 100$

3225 BC

$\delta^{13} \mathrm{C}=-27.1 \%$ $8.13 \mathrm{~m}$.

Top of upper leaf of lower peat within Fen Clay at depth 8.08 to

\section{IGS-C14/122. (St 3841)}

$5600 \pm 100$

$3650 \mathrm{BC}$

$\delta^{13} \mathrm{C}=-27.9 \%$ $8.51 \mathrm{~m}$.

Base of upper leaf of lower peat within Fen Clay at depth 8.48 to

\section{IGS-C14/123. (St 3824)}

$5905 \pm 100$

3955 BC

$\delta^{13} \mathrm{C}=-24.3 \%$

Sample from lower leaf of lower peat within Fen Clay at depth 8.74 to $8.76 \mathrm{~m}$.

IGS-C14/124. (St 3847)

$1875 \pm 100$ AD 75

$\delta^{13} \mathrm{C}=-28.6 \%$

Phragmites roots at depth $2.1 \mathrm{~m}$ in borehole Spalding $4,\left(52^{\circ} 45^{\prime} \mathrm{N}\right.$, $0^{\circ} 10^{\prime}$ W, Grid Ref TF 2417 1914). Coll 1971 and subm. by A Horton. General Comment (AH): samples provide data on development and relative rates of deposition of Fen Clay sequence of the Fens. Dates indicate that peat growth may not have begun nor ended isochronously throughout area.

\section{IGS-C14/125. (St 3872) Woodston, Peterborough $>40,000$ $\delta^{13} \mathrm{C}=-24.9 \%$}

Wood from gravel bed near base of Woodston series at depth $2.4 \mathrm{~m}$ in drainage trench at Woodston, Peterborough, $\left(52^{\circ} 33^{\prime} \mathrm{N}, 0^{\circ} 16^{\prime} \mathrm{W}\right.$, Grid Ref TL 1799 9608). Coll 1971 and subm by A Horton. Comment $(\mathrm{AH})$ : date accords with interglacial age deduced from flora.

\section{Setch series, Norfolk}

Peats from Nar Valley 1 Borehole $\left(52^{\circ} 42^{\prime} \mathrm{N}, 0^{\circ} 25^{\prime} \mathrm{E}\right.$, Grid Ref TF 6295 1327). Coll 1971 and subm by R W Gallois, Inst Geol Sci.

IGS-C14/126. (St 3843)

$$
1875 \pm 100
$$

AD 75

${ }^{1 s} C=-26.7 \%$

Peat from upper part of $1.1 \mathrm{~m}$ bed, $3.7 \mathrm{~m}$ below surface. 
IGS-C14/127. (St 3868)

Peat from lower part of same bed as $/ 126,4.7 \mathrm{~m}$ below surface.

\section{IGS-C14/128. （St 3865）}

$$
\begin{gathered}
\mathbf{5 4 4 0} \pm 100 \\
\mathbf{3 4 9 0} \text { BC } \\
\delta^{1 s} C=-27.6 \%
\end{gathered}
$$

Peat from near base of $0.69 \mathrm{~m}$ bed, $7.3 \mathrm{~m}$ below surface.

General Comment (RWG): /126 and /127 are the upper peats of the Fenland Holocene sequence, and /128 is the lower peat. The difference in date between / 126 and / 127 appears anomalous for such a thin bed of peat.

IGS-C14/129. (St 3874) Setch, Norfolk

$$
\begin{aligned}
& >\mathbf{4 0 , 0 0 0} \\
\delta^{13} \mathrm{C} & =-31.0 \%
\end{aligned}
$$

Peat from bed $0.69 \mathrm{~m}$ thick at $12.8 \mathrm{~m}$ below surface in Nar Valley 4 Borehole $\left(52^{\circ} 42^{\prime} \mathrm{N}, 0^{\circ} 26^{\prime} \mathrm{E}\right.$, Grid Ref TF 6502 1419). Coll 1971 and subm by R W Gallois. Comment (RWG): part of Nar Valley Freshwater Beds; infinite date does not conflict with presumed Hoxnian age of these deposits (Stevens, 1958).

\section{Glaspwll series, Machynlleth, Montgomeryshire}

\section{IGS-C14/131. (St 3873)}

Ditch, Garthgwinion (52० $34^{\prime}$ N, $3^{\circ} 52^{\prime} \mathrm{W}$, Grid Ref SN 73599803 ). Sample of wood from bottom of ditch, $0.91 \mathrm{~m}$ below top of peat. Coll 1971 and subm by R Cave, Inst Geol Sci.

\section{IGS-C14/132. (St 3867)}

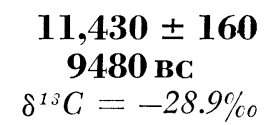

Ditch, Garthgwinion (52 $34^{\prime}$ N, $3^{\circ} 52^{\prime}$ W, Grid Ref SN 7367 9791). Sample of plant remains in diatomaceous silt beneath $1.22 \mathrm{~m}$ to $1.52 \mathrm{~m}$ dark peat, the latter probably continuous with $0.91 \mathrm{~m}$ peat of IGS-131. Coll 1971 and subm by R Cave.

IGS-C14/133. (St 3820)

Ditch, Garthgwinion (52 $34^{\prime}$ N, $3^{\circ} 52^{\prime}$ W, Grid Ref SN 73559803$)$. Sample from $0.08 \mathrm{~m}$ layer of peat, underlying $0.30 \mathrm{~m}$ to $0.60 \mathrm{~m}$ fawn, silty gravel (Head or ditch diggings) and overlying $0.60 \mathrm{~m}$ fine, solifluction gravel (Head). Coll 1971 and subm by R Cave.

\section{Poulton-le-Fylde series, Lancashire}

Coarse detrital mud ( $53^{\circ} 50^{\prime} \mathrm{N}, 3^{\circ} 1^{\prime} \mathrm{W}$, Grid Ref SD 3312 3867) with skeleton of male elk (Alces alces, L.) bearing lesions from two attacks by hunters ca 2-3 weeks apart; two uniserial barbed bone points of Meso- 
lithic type were assoc. Level assigned to the Aller $\phi \mathrm{d}$ period (Zone II) (Barnes et al, 1971; Hallam et al, in press). Coll 1970 by B Barnes, subm by B J N Edwards.

\section{IGS-C14/134. (St 3836)}

Sample from +11.97 to $+11.95 \mathrm{~m}$ OD.

IGS-C14/135. (St 3832)

Sample from +11.90 to $+11.87 \mathrm{~m} \mathrm{OD}$.
$11,665 \pm 140$ 9715 BC $\delta^{13} C=-23.7 \%$

$12,200 \pm 160$

$10,250 \mathrm{BC}$

$\delta^{18} \mathrm{C}=-18.6 \%$

General Comment (BJNE): determinations support Aller $\phi$ d dating and that for a Zone II level at Skitham, Out Rawcliffe $(11,170+260 \mathrm{BP}$ GaK-2820).

IGS-C14/136. (St 3801, outer fraction)

Foulness Island, Essex

$4265 \pm 100$

(St 3802, inner fraction)

Foulness Island, Essex

$2315 \mathrm{BC}$

$4350 \pm 210$

2400 BC

$\delta^{13} \mathrm{C}=-1.5 \%$

Mixed shells from $7.92 \mathrm{~m}$ in borehole $\left(51^{\circ} 36^{\prime} \mathrm{N}, 0^{\circ} 55^{\prime} \mathrm{E}\right.$, Grid Ref TM 029 940). Coll 1969 and subm by J T Greensmith, Queen Mary College. Comment (JTG): dates initiation of phase of shell accumulation in vicinity of proto-Crouch and proto-Roach river mouths, reaching climax in formation of shell banks and cheniers at 4000 to $3500 \mathrm{BP}$ (Birm-243) (Greensmith and Tucker, 1971).

IGS-C14/137. (St 3799, outer fraction)

Dengie Peninsula, Essex

$800 \pm 100$

AD 1150

(St 3800, inner fraction)

Dengie Peninsula, Essex

$$
\delta^{1.5} \mathrm{C}=-7.9 \%
$$

AD 1305

$645 \pm 100$

$\delta^{13} \mathrm{C}=-7.6 \%$

Shells (Cardium) from $1.3 \mathrm{~m}$ in Dengie No 2 Borehole $\left(51^{\circ} 39^{\prime} \mathrm{N}\right.$, $0^{\circ} 54^{\prime}$ E, Grid Ref TM 012 995). Coll 1967 and subm by J T Greensmith. Comment (JTG): date indicates that area on $\mathrm{W}$ side of Dengie inland chenier zone was open to marine influence long after period when chenier formation ceased.

IGS-C14/138. (St 3807, outer fraction)

Dengie Peninsula, Essex

$1410 \pm 100$

AD 540

(St 3808, inner fraction)

Dengie Peninsula, Essex

$$
\begin{aligned}
& \delta^{13} C=-0.6 \% \\
& \mathbf{1 3 4 0} \pm \mathbf{1 0 0} \\
& \mathbf{A D 6 1 0} \\
& \delta^{13} C=-0.6 \%
\end{aligned}
$$

Shells (Cardium) from $0.9 \mathrm{~m}$ in Dengie No 3 Borehole $\left(51^{\circ} 41^{\prime} \mathrm{N}, 0^{\circ}\right.$ $56^{\prime}$ E, Grid Ref TN 021 028). Coll 1966 and subm by J T Greensmith. 
Comment (JTG): date confirms that Dengie inland chenier zone is postRoman and, together with Birm-244, suggests a 200-yr phase of chenier formation, probably in conjunction with salt marsh erosion (Greensmith and Tucker, 1969).

\section{IGS-C14/139. (St 3798) Foulness Island, Essex $4670 \mathrm{BC}$ \\ $\delta^{13} C=+1.5 \%$}

$6620 \pm 100$

Shells (Ostrea) from 13.72 to $15.24 \mathrm{~m}$ in Borehole $\mathrm{R} / 11 / 1\left(51^{\circ} 36^{\prime} \mathrm{N}\right.$, $0^{\circ} 54^{\prime}$ E, Grid Ref TM 018 943). Coll 1969 and subm by J T Greensmith.

\section{IGS-C14/140. (St 3797) Foulness Sands, Essex}

$5650 \pm 240$

3700 BC

$\delta^{13} \mathrm{C}=-3.4 \%$

Shells (Ostrea) from 12.19 to $13.72 \mathrm{~m}$ in Borehole $\mathrm{R} / 7 / 1\left(51^{\circ} 36^{\prime} \mathrm{N}\right.$, $0^{\circ} 57^{\prime}$ E, Grid Ref TM 050 940). Coll 1969 and subm by J T Greensmith. General Comment (JTG): both dates represent marked phases of Ostrea colonization at mouths of proto-Crouch and proto-Roach rivers.

\section{REFERENCES}

Barnes, B, Edwards, B J N, Hallam, J S, and Stuart, A J, 1971, Skeleton of a Late Glacial Elk associated with Barbed Points from Poulton-le-Fylde, Lancashire: Nature, v 232, p 488-489.

Bristow, C R and Cox, F C, 1973, The Gipping Till; a reappraisal of East Anglian glacial stratigraphy: Geol Soc London Jour, v 129, p 1-37.

Conway, B W, 1972, Geological investigation of Boyn Hill terrace deposits at Barnfield Pit, Swanscombe, Kent, during 1971: Royal Anthropol Inst Proc, 1971, p $73-85$.

Evans, P, 1971, Towards a Pleistocene time-scale. Part 2 of The Phanerozoic Timescale-_a supplement: Geol Soc spec pub no. 5, London, p 123-356.

Franks, J W, 1960, Interglacial deposits at Trafalgar Square, London: New Phytologist, $v$ 59, p 145-152.

Franks, J W, Sutcliffe, A J, Kerney, M P, and Coope, G R, 1958, Haunt of elephant and rhinoceros: the 'Trafalgar Square of 100,000 years ago-new discoveries: Illus London News, 14 June 1958, p 1011-1013.

Greensmith, I T and Tucker, E V, 1969. The origin of Holocene shell deposits in the chenier plain facies of Essex, England: Marine Geol, v 7, p 403-425.

1971, The effects of late Pleistocene and Holocene sea-level changes in the vicinity of the River Crouch, east Essex: Geol Assoc Proc, v 82, p 301-322.

Hallam, J S et al, in press, The remains of a late Glacial Elk associated with Barbed Points from High Furlong, Poulton-le-Fylde, near Blackpool, Lancashire: Prehist Soc Proc.

Jessen, K, 1949, Studies in Late Quaternary deposits and flora-history of Ireland: Royal Irish Acad Proc, v 52B, p 85-290.

Kerney, M P, 1971, Interglacial deposits in Barnfield pit, Swanscombe, and their molluscan fauna: Geol Soc Jour, v 127, p 69-93.

Ovey, C D (ed), 1964, The Swanscombe Skull: R Anthrop Inst Occ Paper no. 20.

Page, N R, 1972, On the age of the Hoxnian interglacial: Geol Jour, v. 8, p 129-142.

Stevens, L A, 1958, The interglacial of the Nar Valley, Norfolk: Geol Soc London Quart Jour, v. 115, p 291-315.

Welin, E, Engstrand, L, and Vaczy, S, 1971, Institute of Geological Sciences radiocarbon dates I: Radiocarbon, v 13, p 26-28.

1972, Institute of Geological Sciences radiocarbon dates III: Radiocarbon, v 14, p 331-335. 